2. Бордовская Н. В. Педагогика: [учебник для вузов] / Н. В. Бордовская, А. А. Реан. - СПб. : Питер, 2001. - 304 с.

3. Введенский В. М. Моделирование профессиональной компетентности педагога / В. М. Введенский // Педагогика. - 2003. - № 10. - С. 51-55.

4. Власенко О. М. Формування моральних цінностей у майбутніх учителів засобами моделювання педагогічних ситуацій: дис. ... кандидата пед. наук : 13.00.07 / Власенко Ольга Миколаївна. - Житомир, 2005. - 223 с.

5. Никандров В. В. Метод моделирования в психологии: [учеб. пособие] / В. В. Никандров. - Спб. : Речь, 2003. - 55 с.

6. Постова С. Моделювання педагогічних ситуацій як засіб підготовки вчителів до педагогічного спілкування / С. Постова // Педагогіка. - 2011. - №21. - С. 227-233.

7. Спирин Л. Ф. Анализ учебно-воспитательных ситуацій и решение педагогических задач / под ред. В. А. Сластенина. - Ярославль : Изд-во Яросл. пед. инстта, 1974. - $130 \mathrm{c}$.

Стаття надійшла до редакції 23.05.2012 p.

О. Б. Лоштун, кандидат пед.наук, асистент, Криворізький педагогічний інститут ДВНЗ «Криворізький національний університет»

\title{
ПРИНЦИПИ ТРЕНІНГОВОЇ РОБОТИ В СИСТЕМІ ФОРМУВАННЯ ПРОФЕСІЙНОЇ КОМПЕТЕНТНОСТІ МАЙБУТНЬОГО ВЧИТЕЛЯ
}

\begin{abstract}
Лочтун О. Б. Принципи тренінгової роботи в системі формування професійної компетентності майбутнього вчителя.

Статтю присвячено розв'язанню проблеми використанню тренінгу у професійній підготовиі майбутніх учителів. Автором проаналізовано стан проблеми у психолого-педагогічній літературі та визначено принциии реалізащї тренінгових занять у вищій школі.

Ключові слова: професійна компетентність, тренінг, принципи тренінгу.

Лочтун О. Б. Принщипь тренинговой работь в системе формирования профессиональной компетентности будущего учителя.

Статья посвящена решению проблемь использования тренинга в профессиональной подготовке будущих учителей. Автором проанализировано состояние проблемы в психологопедагогической литературе и определены принципы реализации тренинговых занятий в высшей школе.

Ключевые слова: профессиональная компетентность, тренинг, принцииы тренинга.

Loshtun $O$. Principles of training in the formation of professional competence of future teachers

The article is devoted to solving the problem of training in the training of future teachers. The author analyzes the problems in the psychological and educational literature and defines the principles of the implementation of training sessions in high school.
\end{abstract}

Key words: professional competence, training, training principles.

Постановка проблеми. Сучасна вища освіта, як зазначається в Національній доктрині розвитку освіти України у XXI столітті, має забезпечити підготовку активного, самостійного, творчого фахівця, здатного до постійного пошуку нестандартних способів розв'язання будь-якого виробничого завдання, використання досягнень науково-технічного прогресу, реалізації та самореалізації своїх сутнісних сил у різних видах діяльності.

Проте для вищої школи залишається характерною традиційно сформована система підготовки майбутнього вчителя, що припускає 
виникнення суперечностей між потребою школи у творчому вчителеві та перевагою в практиці вищих навчальних закладів репродуктивних форм i методів професійної підготовки, часто неефективних і ненадійних в умовах модернізації вищої освіти, створенні умов для розвитку особистості й творчої самореалізації майбутнього фахівця. ВНЗ повинні забезпечити створення нових умов для підготовки сучасного фахівця, який водночас має мати фундаментальні знання, розвинені творчі здібності, здатність до самоосвіти.

Зв'язок проблеми 3 науковими програмами, планами, темами. Дослідженню проблеми професійної підготовки майбутніх фахівців у вищій школі завжди приділялася належна увага, зокрема, таким аспектам: методологічні засади сучасної філософії освіти (В. Андрющенко, В. Кремень, I. Зязюн), проблеми неперервної професійної освіти (С. Гончаренко, Н. Ничкало) та професійної підготовки фахівців у вищій школі (А. Алексюк, H. Мойсеюк, О. Романовський, Л. Товажнянський); розроблення та впровадження сучасних педагогічних технологій професійної підготовки фахівців (В. Беспалько, С. Сисоєва) та професійна підготовка майбутніх фахівців у контексті особистісно-орієнтованої освіти (Г. Балл, В. Рибалка).

М. Елькін уважає, що «професійна компетентність вчителя - це інтегральна особистісна якість, яка характеризує його здатність до розв'язання професійних проблем i типових професійних завдань, що виникають у реальних ситуаціях педагогічної діяльності, 3 використанням знань, умінь, навичок і нахилів, освітнього і життєвого досвіду, цінностей» [5, с. 30].

Мета статті. Отже, професійна компетентність педагога передбачає сукупність особливих характеристик особистості вчителя, які набуваються ним на різних етапах його професійного становлення і за умови виконання різнохарактерної діяльності. 3 огляду на це, досягти високого рівня інтелектуального розвитку особистості можна тільки через новий підхід до використання форм активізації пізнавальної діяльності, з-поміж яких ми виокремлюємо тренінгову роботу студентів, яка бере участь у формуванні професійної компетентності майбутнього вчителя.

Виклад основного матеріалу. Останнім часом у працях науковців значна увага приділяється впровадженню тренінгової підготовки (Г. Ковальчук, О. Куклін, Т. Поясок, О. Щербак).

Л. Бондарєва, розглядаючи питання застосування тренінгу, пропонує таке формулювання: «Навчальний тренінг - це активна навчальна діяльність студентів, під час здійснення якої майбутні фахівці виконують тренінгові вправи адаптовані до майбутньої професійної діяльності під керівництвом викладача-тренера на основі спеціально підготовлених інструктивнометодичних матеріалів відповідних сучасним вимогам до професійної діяльності» [1, с.7].

Теоретичний аналіз проблеми професійної підготовки студентів вищих навчальних закладів засобами навчального тренінгу переконує, що навчальний тренінг розглядається як важливий складник професійного навчання, що має своїм завданням формування відповідних навичок та умінь (С. Гончаренко); 
сплановані і систематизовані зусилля 3 модифікації або розвитку умінь i установок людини засобами навчання для ефективного виконання одного чи декілька видів діяльності (Р. Баклі, Д. Кейпл); інтенсивне навчання 3 практичною спрямованістю (Б. Бім-Бад); активна навчальна діяльність, під час здійснення якої студенти визначають (або тренують) способи, системи, явища, процеси майбутньої професійної діяльності (О. Аксьонова).

Тренінг - це заплановані та систематичні зусилля 3 розвитку та вдосконалення знань, навичок, умінь та установок студента за допомогою емпіричних засобів навчання. У процесі тренінгу отримується не лише нова інформація, а з’являється можливість відразу використовувати їі на практиці, виробляючи нові навички.

Тренінг базується на принципах, що кардинально відрізняють його від традиційного навчання. І. Вачков [3] виокремлює такі принципи реалізації тренінгових занять:

1. Принцип «подієвості» - організація руху. Під час проведення тренінгових занять педагог має забезпечити їх перетворення в ланцюг взаємопов'язаних подій, які учасники переживатимуть як цілісність, єдність, нерозривність змін, що відбуваються 3 ними навколишніми. Наприклад, під час проведення занять 3 профорієнтаційної роботи можна вчити студентів як правильно інформувати учнів про наявність ВНЗ у місті, як консультувати старшокласників за результатами психодіагностувальних тестів і пояснювати, до якого типу професій більш схильний учень. А можна організувати саме тренінг з використанням профорієнтаційних вправ та ігор професійного та особистісного самовизначення, в процесі яких учасники навчаться відкривати не лише нові властивості та якості, а й нові можливості.

2. Принцип метафоризації - організація простору. Особливої уваги надається використанню символів, образів, метафор, через які учаснику тренінгу вдається впізнати себе і відчути свою єдність з іншими.

3. Принцип трансспективи - організація часу. Педагог має орієнтуватися на створення в тренінгу умов для проживання учасниками подій в їх єдності та нерозривності з подіями минулого і майбутнього.

Крім того, до принципів, що покладено в основу тренінгу, можна відносити такі.

Принции активності. У тренінгу студенти залучаються до спеціально розроблених дій (програвання тієї чи іншої ситуації, виконання вправ, спостереження за спеціальною схемою). Особливо ефективними для досягнення цілей тренінгу є ті ситуації, які дозволяють брати участь усім учасникам одночасно.

Принциип дослідницьької (творчої) позищзї. Викладач організовує ситуації, які сприяють розвитку творчості та дають можливість членам групи усвідомити, апробувати нові способи поводження, експериментувати з ними. Під час тренінгу учасники групи знаходять і усвідомлюють вже відомі ідеї та закономірності, а також розкривають та удосконалюють особисті якості та здібності. 
Принцип об’єктивації (усвідомлення) поведінки. Для здійснення цього принципу використовуються додаткові засоби (наприклад, відеозапис поводження учасників групи в тих чи інших ситуаціях 3 наступним переглядом i обговоренням). Внадало організовані заняття переводять поведінку учасників з імпульсного на об'єктивований рівень, що дозволяє здійснювати зміни в тренінгу.

Принцип партнерського (суб'єкт-суб'єктного) спілкування. Враховуються інтереси інших учасників взаємодії, їхні почуття, емоції, переживання, визнається цінність особистості іншої людини.

Переваги тренінгу в тому, «<..> щоб перетворити групу в своєрідне дзеркало, або точніше, систему дзеркал в процесі своїх конкретних проявів у житті певної групи» [4, с. 37]. Тому цілком природнім $є$ принцип обмеження обговорення подій лише в рамках тренінгу («тут і тепер») і персоніфікація висловлювань. Для учасників тренінгу нерідко характерною є тенденція до відхилення від основної теми, схильність до загальних розмов, міркувань, далеких від змісту тренінгу. Цей принцип орієнтує учасників на те, щоб предметом їх аналізу постійно були процеси, які відбуваються в групі у конкретний момент.

Принции акцентування сприяє глибокій рефлексії учасників, вчить учасників зосереджувати увагу на думках, почуттях, розвиває навички самоаналізу. Навіть оцінка поведінки має здійснюватися через висловлення власних почуттів і переживань. Відмова від безособових мовленнєвих форм допомагає людям у повсякденному спілкуванні приховувати власну позицію й уникати відповідальності. Забороняється використовувати висловлювання на зразок: «Більшість моїх друзів уважає...», «Ми думаємо...», «Ми маємо іншу думку...» тощо, якими перекладається відповідальність за почуття i думки конкретної людини на аморфне «ми», і цим самим роблять іiі знеособленою. Усі висловлювання повинні будуватися 3 використанням особових займенників однини: «Я думаю...», «Я переконаний...», «Я відчуваю...», «Мені приємно...» та ін. Використання вказаного принципу допомагає розв'язати одне із завдань тренінгу - навчитися брати відповідальність на себе і приймати себе таким, яким $є$.

Успіх тренінгових занять також залежить від реалізації приниипу «щирості й відкритості». Найголовніше тут - не обманювати, бути щирим, відвертим. С. Джурад підкреслював, що розкриття свого «Я» іншому є знаком сильної й здорової особистості. Саморозкриття спрямоване на іншу людину, але дозволяє стати собою і зустрітися із собою справжнім. Щирість i відкритість сприяє одержанню й наданню іншим чесного зворотного зв'язку, тобто тієї інформації, яка $\epsilon$ важливою для кожного учасника i запускає механізми розвитку самосвідомості та механізми взаємодії у групі.

Принцип акцентуації мовлення почуттів. Емоційна сторона спілкування має бути добре і повно вираженою учасниками тренінгу; їм рекомендується акцентувати увагу на станах і виявленняах (своїх власних і партнерів) і при відтворенні зворотного зв'язку, якщо можливо, використовувати мову, яка 
відображає цей стан. Прикладом цього може слугувати така констатація: «Твоя манера розмовляти на підвищених тонах дратує мене». Більш опосередковану форму мовлення почуттів утворює мова образів, асоціацій і метафор, які використовуються в тренінгу як на вербальному, так і невербальному рівні. Опосередкована мова, як правило, менш травмує і $є$ менш жорсткою, що суттєво, якщо потрібно повідомити не дуже приємну інформацію.

Важливим принципом тренінгу $є$ уникнення безпосередніх оцінок людини, замінюючи їх описом власних емоційних станів, оскільки вірогідність неприйняття негативного зворотного зв'язку зростає тоді, коли остання має суто оцінювальний характер. Не бажано використовувати висловлювання: «Ти мені не подобаєшся», потрібно сказати: «Мені не подобається твоя поведінка» тощо. Відомо, що негативна інформація активізує захисні механізми особистості і нерідко відкидається.

Принцип довірливого спілкування- один із фундаментальних елементів тренінгу. Розвиток довірливого клімату - складний процес. Кожний реалізує той рівень відкритості, до якого він готовий, залежно від своїх особливостей і загального рівня довірливості в групі.

Висновки та перспективи подальших розвідок. Отже, тренінгові заняття у вищій школі, передовсім, орієнтовані на запитання та пошук. На відміну від традиційних, тренінгові форми навчання ініціалізують весь потенціал людини: рівень та обсяг її видів компетентностей, які мають місце в професійній діяльності (соціальна, соціально-психологічна, цілевизначальна, комунікативна, технологічна, продуктивно-результативна, прогностична, аналітико-синтетична, ситуативна, організаційна, емоційна та інтелектуальна), самостійність, здатність до прийняття рішень, до взаємодії тощо.

\section{Література}

1. Бондарєва Л. І. Навчальний тренінг як засіб професійної підготовки майбутніх менеджерів організацій в економічних університетах: автореф. дис. на здобуття наук. ступеня канд. пед. наук: спец. 13.00.04 «Теорія і методика професійної освіти» / Л. І. Бондарєва. - К., 2006.- 20 с.

2. Вачков И. В. Психология тренинговой работы: Содержательные, организационные и методические аспекты ведения тренинговой группы / И. В. Вачков. М. : Эксмо, 2007. - 416 с.

3. Литовченко Н. Ф. Професійно орієнтований тренінг самопізнання та саморегуляції : [навч.-метод. матеріали для тренінгових занять студ. пед. вузів] / Н. Ф. Литовченко. - Ніжин : НДПУ,2002. - 72c.

4. Петровская Л. А. Теоретические и методические проблемы социальнопсихологического тренинга / Л. А. Петровская. - М. : Изд-во МГУ, 1982. - 168 с.

5. Елькін М. В. Формування професійної компетентності майбутніх керівників сільської школи в умовах магістратури / М.В. Елькін // Управління школою. - 2007. № 33. - C. 29-31.

Стаття надійшла до редакції 23.05.2012 p. 